\title{
Analisis Butir Soal Ujian Semester Kelas VIII Mata Pelajaran Bahasa Indonesia
}

\author{
Agus Milu Susetyo \\ Universitas Muhammadiyah Jember \\ agusmilus@unmuhjember.ac.id
}

DOI: https://doi.org/10.32528/bb.v5i2.2789

First received: 19-12-2019 Final proof received: 23-09-2020

\begin{abstract}
ABSTRAK
Butir soal yang diberikan kepada siswa sangat perlu untuk di analisis. Analisis ini mulai dari tingkat kesukaran, daya beda dan daya pengecoh khusus pada soal tipe pilihan ganda. Hal ini dilakukan untuk menjadikan instrumen asesmen menjadi berkualitas dan valid. Peneliti telah melakukan analisis tersebut dengan metode penelitian kualitatif deskriptif. Sumber data yang peneliti gunakan adalah lembar jawaban siswa kelas VIII di SMP Muhammadiyah 1 Jember. Sementara itu, data yang dipakai dalam penelitian ini adalah dokumentasi angka atau skor dari jawaban siswa. Selanjutnya tahapan dari analisis data dalam penelitian ini adalah reduksi, penyajian dan penarikan kesimpulan. Usaha untuk memperoleh keabsahan data peneliti menggunakan teknik ketekunan pengamatan. Hasil penelitian menunjukkan beberapa hal sebagai berikut. Pertama, dilihat dari tingkat kesukaran butir soal terdapat 5 jenis tingkat kesukaran di 40 butir pilihan ganda yaitu sangat mudah (3 soal), mudah ( 9 soal), sedang (22 soal), sukar (3 soal), sangat sukar (3 soal). Sementara itu, untuk soal uraian semuanya (5 soal) berkategori sedang. Kedua, dilihat dari daya pembeda tiap butir terdapat empat jenis yaitu dapat digunakan (9 soal), digunakan dengan revisi (5 soal), revisi (2 soal) dan dibuang (24 soal) untuk tipe soal pilihan ganda. Sementara itu, untuk soal uraian yang terdiri dari 5 soal berkategori dapat digunakan tapi revisi. Ketiga, dilihat dari daya pengecoh butir soal pada pilihan ganda terdapat 16 butir soal dengan daya pengecoh baik dan 24 butir soal dengan daya pengecohnya tidak baik. Kegagalan butir soal ini dikarenakan tidak validnya soal yang disusun guru. Artinya soal yang disajikan saat ujian tidak bisa atau tidak tepat untuk mengukur atau tidak tepat untuk mengetes siswa sesuai kompetensi yang diujikan. Kevalidan soal bisa dilihat dari analisis daya beda, tingkat kesusakaran dan efektivitas pengecoh khususnya pada soal pilihan ganda. Soal yang tidak memenuhi tiga kriteria harus di revisi dan diganti dengan soal yang baru. Namun tetap bisa saja digunakan untuk kegiatan tes-tes yang sifatnya lebih ketat atau sangat longgar.
\end{abstract}

Keywords: analisis; butir soal; ujian; daya beda; tingkat kesukaran; pengecoh 


\begin{abstract}
Question items given to students are necessary to be analyzed. The analysis starts from level of difficulty, differences power, and distracting power that specifically for multiple choice questions. This is done to make the assesment instrument become qualified and valid. Researcher has done the analysis by using descriptive qualitative reasearch method.The data source in this study was the answer sheet of class VIII students at SMP Muhammadiyah 1 Jember. Meanwhile, the data used in this study was documentation of numbers or scores from students' answers. Furthermore, the stages of data analysis in this study were reduction, presentation and conclusion. Efforts to obtain the validity the researcher's data used perseverance observation techniques. The results of the study showed several things as follows. First, judging from the level of difficulty of the items, there were 5 types of difficulty in 40 multiple choice items namely very easy (3 questions), easy ( 9 questions), medium (22 questions), difficult (3 questions), very difficult (3 questions). Meanwhile, for all description questions (5 questions) were in the medium category. Second, judging from the power of difference of each item, there were four types, which can be used (9 questions), used with revisions (5 questions), revisions (2 questions) and discarded (24 questions) for the type of multiple choice questions. Meanwhile, for the description questions that consisting of 5 questions, those questions could be used but revised. Third, judging from the deceptive power in multiple choices, there were 16 items with good deception and 24 items with poor deception. The failure of this item was due to the invalid questions prepared by the teacher. This means that the questions presented during the exam cannot or are not appropriate to measure or are not appropriate to test students according to the competencies being tested. The validity of the questions can be seen from the analysis of discrepancies, the level of difficulty and the effectiveness of distractors, especially in multiple choice questions. Questions that do not meet the three criteria must be revised and replaced with new questions. However, it can still be used for tests that are more stringent or very loose.
\end{abstract}

Keywords: analysis; item test; power of difference; difficulty level; distractor

\title{
1. PENDAHULUAN
}

Ada tiga yang sering membuat para guru atau sebagian diantara kita bingung adalah evaluasi, penilaian dan pengetesan. Hal ini karena banyak diantara kita bahwa beberapa buku bacaan ada yang membedakan ada juga yang menyamakan. Menurut Nuriyah (2014: hal 73) menjelaskan bahwa penilaian merupakan kegiatan pengumpulan informasi dengan tujuan menentukan sejauh mana ketercapaian tujuan pembelajaran. Alatnya bisa berupa tes, kuesioner, wawancara, dan observasi. Aspek yang dinilai bisa meliputi pengetahuan, keterampilan dan sikap siswa. Sementara itu, pengetesan adalah salah satu prosedur yang dapat digunakan untuk melihat ketercapaian kompetensi siswa sedangkan evaluasi adalah interpretasi atau penafsiran berdasarkan data-data hasil pengukuran atau penilaian. Ketiga hal ini tidak dapat dipisahkan dalam kegiatan pembelajaran. 
Salah satu faktor guru bisa dikatakan mempunyai kompetensi pedagogik jika bisa melaksanakan penilaian dan evaluasi program pembelajaran. Kemampuan ini tentunya tidak datang dengan sendirinya. Ada unsur kesengajaan dan keteguhan dari diri seorang guru untuk meningkatkan kualitas sebagai pendidik. Menurut Indriani (2015. hal 17) menyatakan bahwa salah satu tugas guru adalah menilai dan mengevaluasi peserta didiknya. Hal ini mengindikasikan bahwa guru harus bisa merencanan tindakan penilaian atau evaluasi, melakukan evaluasi, dan melaporkan hasil evaluasi atau penilaian. Dengan demikian penilaian (evaluasi) pembelajaran akan memberikan informasi keberhasilan belajar siswa dapat diketahui. Caranya adalah dengan memberikan alat atau instrumen penilaian hasil belajar kepada peserta didik.

Kualitas instrumen dapat ditentukan oleh faktor reliabilitas dan validitasnya. Menurut Nuriyah (2014, Hal. 17) menjelaskan bahwa reliabel adalah ukuran sejauh mana suatu alat atau instrumen dapat diandalkan. Artinya adalah apabila instrumen tes digunakan dapat digunakan dalam situasi, waktu apapun hasilnya relatif sama. Analoginya misalnya untuk menimbang sekarung beras yang tertulis berat bersihnya 50 $\mathrm{kg}$ dan timbangan tersebut memang menunjukkan angka $50 \mathrm{~kg}$ meskipun berapa kali pengujian. Sementara itu, validitas adalah kekampuan butir istrumen atau alat ukur mampu mengukur yang apa yang seharusnya diukur. Sebagai ilustrasinya, pengaris sangat tepat untuk mengukur panjang, timbangan digunakan untuk mengukur berat. Meteran tidak bisa digunakan untuk menentukan berat suatu benda.

Ada banyak cara yang dapat dilakukan guru untuk menguji apakah soal atau instrumen tesnya sudah valid dan reliabel atau belum. Salah satu caranya adalah diadakan analisis butir soal. Analisis ini maksudnya soal yang akan diberikan kepada siswa atau peserta didik dites terlebih dahulu. Tujuan dari proses ini adalah untuk menelaah butir soal sehingga mendapatkan butir soal yang berkualitas. Tidak menutup kemungkinan analisis butir soal dilakukan setelah soal diujikan. sHal tersesbut berguna untuk membantu guru merevisi atau membuang soal serta dapat mengetahui kemampuan siswa yang diuji.

Analisis butir soal merupakan cara lain untuk membuat instrumen penilaian yang berkualias. Nayla dan Ani (2012. hal 4) menyatakan bahwa analisis butis soal kegiatan yang dilakukan guru untuk mengukur kualitas soal yang telah dibuat. Kegiatan ini pulalah yang guru harus lakukan jika ingin mengukur dengan tepat keberhasilan belajar siswanya. Instrumen tes atau soal yang bermutu adalah soal yang mampu memberikan informasi setepat-tepanya tentang kemampuan atau kompetensi yang diujikan. Dengan soal yang bermutu akan terlihat siswa yang telah dan belum menguasai pelajaran.

Analisis butir soal yang dimaksud dalam penelitian ini adalah analisis tingkat kesukaran soal, daya beda dan daya pengecoh soal pilihan ganda yang digu-nakan oleh guru Bahasa Indonesia pada saat mengadakan Ujian Semester di SMP Muhamdiyah 1 Jember. Peneliti mempu-nyai ketertarikan untuk mendeskripsikan tiga hasil analisis tersebut karena proses ini mempunyai banyak manfaat dan hasil dari penelitian ini bisa dimanfaatkan oleh guru di sekolah mitra.

Penelitian ini memfokuskan pada analisis butir soal. Ada dua cara mengkaji butir soal: cara kualitatif dan kuantitatif. Masing-masing teknik tersebut memiliki keunggulan 
dan kelemahan masing-masing (Wahidmurni, 2010:117). Penelitian yang akan dilakukan menggunakan metode kuantitatif dalam menelaah butir soal. Analisis butir soal secara kuantitatif memiliki dua cara, yaitu cara klasik dan modern. Cara klasik adalah teknik penelahan butir soal dengan menggunakan jawaban yang diberikan siwa setelah soal diberikan. Teknik ini memiliki beberapa kelebihan. (a) murah, (b) cepat prosesnya, (c) sederhana, (d) tidak rumit prosesnya. Peneliti memadukan teknik kuanlitatif dengan pendekatan pendekatan statistik didasarkan pada pada empirik. Data empirik ini didapat dari lembar jawaban siswa yang telah dikoreksi oleh gurunya. Cara yang dimaksud analisis butir soal dengan metode kualitatif adalah dengan menganalisis tingkat kesukaran, daya beda tiap butir soal dan daya pengecoh pada soal pilihan ganda untuk mendapatkat kualitas naskah soal ujian semester.

Penelitian tentang analisis butir soal seperti ini juga pernah dilakukan oleh Nurul Septiana pada tahuan 2016 dengan judul "Analisis Butir Soal Ulangan Akhir Semester (Uas) Biologi Tahun Pelajaran 2015/2016 Kelas x Dan Xi Pada Man Sampit”. Hasil penelitiannya menunjukkan bahwa pada soal kelas X dan XI memiliki kualitas cukup baik, karena sudah sesuai dengan soal standar, tetapi perlu perbaikan aspek materi dan konstruksi pada beberapa soal. Selain itu tingkat kesukaran, daya beda, dan efektifitas daya pengecohnya sangat variatif. Soal ulangan di MAN Sampit terdapat soal yang sukar, sedang dan mudah, daya bedanya ada yang baik, cukup dan jelek dekimian juga dengan daya pengecohnya.

Penelitian tentang analisis butir soal juga pernah dilakukan oleh Tutut Kurniawan pada tahun 2015. Tutut memberi judul penelitiannya "Analisis Butir Soal Ulangan Akhir Semester Gasal Mata Pelajaran IPS Sekolah Dasar". Hal yang membedakan dari penelitian sebelumnya di bahas adalah pada penelitian ini menggunakan jenis ekspos fakto dengan tujuan untuk mengetahui kualitas butir sial pada sial UASnya. Hasilnya menunjukkan bahwa dari aspek tingkat kesukarannya terdapat $68 \%$ soal berkategori mudah, $28 \%$ soal berkategori sedang, dan $4 \%$ soal berkategori sukar. Selain itu, daya pembedanya memperoleh hasil $28 \%$ soal berkategori baik, $28 \%$ soal berkategori cukup, $40 \%$ soal berkategori jelek, dan $4 \%$ soal berkategori jelek sekali sedangkan aspek efektivitas pengecohnya yaitu terdapat $44 \%$ soal berkategori efektif dan $56 \%$ soal berkategori tidak efektif.

Peneliti telah melakukan wawancara secara tidak langsung dengan salah satu guru di SMP Muhammdiyah 1 Jember. Hasil wawancara tersebut menghasilkan beberapa informasi. (a) tiap soal yang dipakai untuk UAS maupun UTS berasal dari hasil diskusi dan pertemuan MKKS. (b) setiap butir soal yang dipakai untuk ujian semester tidak mengalami proses analisis butir soal. (c) sekoah tersebut telah memakai kurikulum K13 dan gurunya disana telah mendapatkan pengalaman pelatihan kurikulum K-13. Hal yang membedakan peneliti ini dengan penelitian di adalah sumber data dan lokasi dan soal yang dipakai ternyata tidak dimengalami perlakukan analisis butir soal sebelumnya. Oleh karena itu, penelitian ini juga bisa memberikan informasi kepada pihak sekolah tentang kualitas atau mutu dari soal mereka.

Berdasarkan latar belakang tersebut peneliti mempunyai keinginan untuk mengalisis butir soal. Meskipun soal ujian semester telah dibuat oleh tim yang 
berkompeten namun mereka merasa yakin bahwa soal yang mereka susun telah bermutu tanpa mengalami proses analisis butir soal. permasalahan pokok dalam penelitin ini yakni bagaimanakah, tingkat kesukaran, daya pembedan dan daya pengecoh dalam soal ujian semester di SMP Muhammadiyah 1 Jember Tahun Pelajaran 2018-2019. Adapun tujuan yang ingin dicapai adalah mendapatkan gambaran atau deskripsi tentang tingkat kesukaran, daya pembedan dan daya pengecoh dalam soal ujian semester di sekolah tersebut.

\section{METODE PENELITIAN}

\section{a. Jenis Penelitian}

Suatu penelitian membutuhkan cara atau prosedur untuk menjawab rumusan masalah atau memahami suatu fenomena yang dikaji. Oleh sebab itu, metode penelitian harus ditentukan oleh peneliti, apakah menggunakan metode kuantiatif atau kualitatif. Masing-masing metode ini memiliki keunggulan dan kekurangan masing-masing. Berbeda masalah atau fokus penelitian berbeda juga metode yang dipakai. Dalam penelitian ini, berdasarkan rumusan masalah yang telah ditentukan di bab sebelumnya, peneliti menggu-nakan metode penelitian dengan pendekatan kualitatif. Fenomena yang dideskripsikan peneliti adalah (a) tingkat kesukaran soal, (b) daya pembeda, dan (c) daya penengocoh ditiap butir soal. Soal yang ditelah peneliti adalah soal ujian semester pada mata pelajaran Bahasa Indonesia kelas VIII di SMP Muhammadiyah 1 Jember. Meskipun tujuannya nanti mendeskripsikan data yang dipakai adalah angka dari jawaban siswa setelah menjawab tiap butir soal yang diujikan semester gasal.

\section{b. Lokasi Penelitian}

Lokasi penelitian harus ditentukan peneliti untuk mendapatkan sumber data peneliti. Lokasi penelitian ini di SMP Muhammdiyah 1 Jember. Adapun beberapa alasan peneliti memilih lokasi tersebut antara lain.

1) Kemudahan memperoleh data penelitian.

2) Belum pernah dilakukan peneliitian dengan fokus yang sama.

3) Guru di lokasi penelitian terutama guru bahasa Indonesia tidak pernah melakukan analisis butir soalnya.

4) Lokasi penelitian yang strategis dan berakreditasi A dari BAN.

\section{c. Data dan Sumber Data Penelitian}

Data penelitian merupakan semua keterangan seseorang yang dijadikan responden maupun yang berasal dari dokumen-dokumen, baik dalam bentuk statistik atau dalam bentuk lainnya guna keperluan penelitian. Data yang dipakai dalam penelitian ini adalah angka atau skor siswa dari soal Ujian Tengah Semester pelajaran Bahasa Indonesia di SMP Muhamdiyah 1 Jember. Meskipun secara jelas dinyatakan bahwa penelitian dengan pendekatan kualitatif tidak mengguna-kanakan angka, penelitian ini justru menggunakan angka dan angka inilah yang nantinya dihitung dan dideskripsikan. sementara itu, data tersebut bersumber dari lembar jawaban siswa kelas VIII. Pemilihan sumber data menggunakan teknik purposif. 


\section{d. Instrumen Penelitian}

Peneliti bertindak sebagai untrumen kunci pada penelitian ini. Adapun beberapa hal yang telah dilakukan penelitian agar siap menjadi instrumen kunci. Pertama, telah berusaha untuk memahami fokus permasalahan dengan menyiapkan beberapa teori yang nantinya digunakan saat mendeskripsikan temuan penelitian. Teorinya antara lain: (a) hakikat evaluasi pembelajaran, (b) hakikat analisis butir soal, (c) tingkat kesukaran soal, (d) daya beda, (e) daya pengecoh pada soal pilihan ganda. Kedua, peneliti telah melakukan upaya untuk memahami latar belakang permasalah dengan melakukan wawancara dan menetapkan fokus penelitian dengan tepat. Ketiga, beberapa kajian metode penelitian yang sesuai telah ditentukan secara sistematis guna mencari jawaban atas permasalah penelitian. Keempat, menyusun instrumen pendukung berupa tabulasi data guna membantu penelitian untuk menganalisis data yang didapat.

\section{e. Teknik Analisis Data}

Terdapat tiga tahap analisis yang diterapkan dalam penelitian ini. antara lain sebagai berikut.

\section{1) Reduksi}

Tahap ini dilakukan dengan membuang data yang tidak diperlukan sehingg menyisakan data yang diharapkan menjadi bahan untuk menjawab masalah yang telah dirumuskan. Setelah data dikumpulkan nanti peneliti akan memilah data yang akan dipakai dan data yang tidak dipakai. Data yang dipakai adalah data sesuai dengan fokus penelitian. Beberapa kriteria data yang laya diambil adalah (a) merupakan hasil karya siswa sendiri, (b) merupakan lembar jawaban milik siswa dari sekolah yang bersangkutan, (c) lembar jawaban mudah dibaca dan diamati letak kesalahan dan kebenarannya berdasarkan kunci jawaban dari guru.

\section{2) Penyajian Data}

Setelah data direduksi, peneliti melakukan proses selanjutnya adalah penyajian data. Data yang dimaksud adalah tabulasi data yang berisi jawaban soal pilihan ganda dan uraian, kunci jawaban. Penyajina ini dilakukan untuk memudahkan peneliti dalam mendesripsikan tingkat kesulitan, daya pembeda dan data pengecoh soal angka dari soal ujian tengah semester mata pela jaran Bahasa Indonesia di SMP Muhammdiyah 1 Jember. Penyajian dalam penelitian ini selain dalam bentuk tabel juga dalam bentuk uraian narasi.

\section{3) Penyimpulan}

Langkah terakhir dari proses analisis ini adalah penyusunan simpulan. Simpulan di peroleh dari hasil penelitian yang telah dibahas di bab pembahasan. Simpulan ini nantinya berisi ringkasan dari hasil penelitian yang telah dilakukan. Selain itu, simpulan nantinya merupakan berisi jawaban dari rumusan masalah yang dijabarkan secara singkat dari temuan penelitian.

\section{f. Pemeriksaan Keabsahan Temuan}

Tahap ini untuk memastikan data yang dikumpulkan valid dan reliabel untuk dilakukan analisis. Jika datanya kredibel, hasil analisis data akan menghasilkan informasi yang dapat dipercaya. Oleh karena itu pada penelitian ini, peneliti menggunakan teknik 
ketekunan pengamatan untuk memastikan data yang diperoleh kredibel. Ketekunan yang dimaksud adalah memeriksa secara mendalam dan hati-hati mulai dari tahap reduksi, memasukkan data dalam bentuk tabel, penyajian data. Ada beberapa jenis pemeriksaan yang dilakukan peneliti. (a) Memeriksa jawaban siswa dengan kunci jawaban dari guru. (b) Memeriksa data ketika sudah dimasukkan ke dalam tabel. (c) Memeriksa secara berkala hasil perhitungan tiap butir soal untuk menentukan deskripsi (Tingkat Kesulitan, Daya Pembeda dan Daya pengecoh) tiap butir soal.

\section{PEMBAHASAN}

Proses analisis soal sangat perlu dilakukan karena kegiatan penilaian, pengukuran dan evaluasi tidak dapat dipasahkan dari proses pembelajaran. Dengan melihat fungsi yang tidak terpisahkan dari proses pembelajaran. Kegiatan penilaian pasti didahului dengn kegiatan pembuatan soal. Selanjutnya adalah guru atau pembuat soal harus menyeleks. Menurut Anatasia (dalam Nurinda dkk, Hal. 79) menyatakan bahwa saat seleksi soal perlu dilakukan untuk dengan cara membuang soal yang sangat mudah sedangkan soal dengan kategori sangat sukar dapat digunakan namun sedikit porsinya. Berdasarkan pendapat tersebut penelitian sangat sesuai dengan kajian teori yang digunakan. Berikut hasil analisis pada soal Ujian Tengah Semester pelajaran Bahasa Indonesia di SMP Muhammadiyah 1 Jember yang telah dilakukan .

\section{a. Hasil Analisis Tingkat Kesukaran Butir Soal Pilihan Ganda (40 Butir Soal)}

Tingkat kesukaran adalah indeks soal yang bisa dijawab benar sesuai dengan kemampuan siswa. Indeks soal dinyatakan dengan angka 0,00 - 1,00. Semakin besar indeks soal berarti semakin mudah soal tersebut. Sebaliknya, semakin rendah indeks soal tersebut artinya semakin mudah atau banyak siswa yang menjawab benar. Tabel berikut ini merupakan indeks untuk menentukan tingkat kesukaran butir soal.

\section{Tabel 1: Indeks Tingkat Kesukaran Soal}

\begin{tabular}{ll}
\hline $\begin{array}{l}\text { Indeks Tingkat } \\
\text { Kesukaran Soal }\end{array}$ & Keterangan \\
\hline $0,00-0,20$ & Sangat sukar \\
\hline $0,21-0,30$ & Sukar \\
\hline $0,31-0,70$ & Sedang \\
\hline $0,71-0,80$ & Mudah \\
\hline
\end{tabular}

Sementara itu rumus yang digunakan untuk menghitung tingkat kesukaran butir soal sebagai berikut.

Rumus untuk tipe soal pilihan ganda

Tingkat Kesukaran $(T K)=\frac{\text { Jumlah siswa yang menjawab benar butir soal }}{\text { jumlah siswa yang mengikuti tes }}$

Rumus untuk tipe soal uraian

$$
\text { Mean }=\frac{\text { Jumlah siswa peserta tes pada suatu soal }}{\text { Jumlah peserta didik yang mengikut tes }}
$$




$$
\text { Tingkat Kesukaran }(T K)=\frac{\text { Mean }}{\text { Skor maksimum yang ditetapkan }}
$$

Sumber: Wahidmurni, 2010, hal. 132

Hasil perhitungan tingkat kesukaran untuk butir soal pilihan ganda.

Tabel 2: perhitungan tingkat kesukaran untuk butir soal pilihan ganda

\begin{tabular}{clc}
\hline No & \multicolumn{1}{c}{ Kriteria } & Jumlah Butir Soal \\
\hline 1 & Sangat mudah & 3 \\
\hline 2 & Mudah & 9 \\
\hline 3 & Sedang & 22 \\
\hline 4 & Sukar & 3 \\
\hline 5 & Kriteria & 3 \\
\hline
\end{tabular}

Berdasarkan tabel di atas diketahui bahwa terdapat variasi kriteria kesukaran butir soal di tipe soal pilihan ganda dari 40 soal. Jika dipersentase sebagai berikut. (a) Terdapat 7,5\% soal dengan kategori sangat mudah yaitu butir soal di nomor 5, 17 dan 32. Soal dengan kategori sangat mudah artinya hampir seluruh siswa kelas VIII mampu menjawab dengan benar sesuai dengan jawaban yang diminta di tiga nomor soal tersebut. (b) Terdapat 7,5\% soal dengan kategori sangat sukar yaitu butir soal di nomor 19, 20 dan 25. Soal dengan kategori sangat sukar artinya Artinya hampir seluruh siswa kelas VIII tidak mampu menjawab dengan benar sesuai dengan jawaban yang diminta di tiga nomor soal tersebut (c) Terdapat 57,5\% soal dengan kategori sedang yaitu soal dengan nomor soal $4,6,7,8,10,14,16,18,21,22,23,24,26,29,31,33,34,35,36,37,39$, dan 40. Soal dengan kategori sedang artinya dari jumlah keseluruhan siswa kelas VIII, setengahnya mampu menjawab dengan benar sesuai dengan jawaban yang diminta dan setengahnya lagi tidak mampu menjawab dengan benar di dua puluh dua nomor soal tersebut. (d) Terdapat 7,5\% soal dengan kategori sukar yaitu soal di nomor 19, 20 dan 25 . Soal dengan kategori sukar artinya sebagian besar siswa kelas VIII tidak mampu menjawab dengan benar sesuai dengan jawaban yang diminta di tiga nomor soal tersebut. (e) Terdapat 7,5\% soal dengan kategori mudah yaitu soal dengan nomor 5, 17 dan 32. Soal dengan kategori mudah artinya sebagian besar siswa kelas VIII mampu menjawab dengan benar sesuai dengan jawaban yang diminta di sembilan nomor soal tersebut.

Hasil perhitungan tingkat kesukaran untuk butir soal uraian.

Tabel 3: Hasil perhitungan tingkat kesukaran untuk butir soal uraian

\begin{tabular}{clc}
\hline No & Kriteria & Jumlah Butir Soal \\
\hline 1 & $\begin{array}{l}\text { Sangat } \\
\text { mudah }\end{array}$ & 0 \\
2 & Mudah & 0 \\
\hline 3 & Sedang & 5 \\
\hline 4 & Sukar & 0 \\
\hline 5 & Kriteria & 0 \\
\hline
\end{tabular}


Berdasarkan tabel di atas diketahui bahwa semua (5 soal) butir soal uraian berkategori sedang. Artinya dari jumlah keseluruhan siswa kelas VIII, setengahnya mampu menjawab dengan benar sesuai dengan jawaban yang diminta dan setengahnya lagi tidak mampu menjawab dengan benar di lima puluh dua nomor soal tersebut.

\section{b. Hasil Analisis Daya Pembeda Butir Soal Pilihan Ganda}

Daya pembeda soal adalah kemampuan yang dimiliki soal untuk membedakan antara siswa yang telah menguasai materi dan siswa yang belum atau tidak menguasai materi (Wahidmurni, 2010, hal. 134). Ini merupakan salah satu cara untuk mengindikasikan suatu butir soal itu berkualitas atau tidak. Daya pembeda ada suatu butir soal dapat dinyatakan dalam bentuk indeks. Tabel berikut merupakan tabel yang berisi indeks untuk menyatakan daya pembeda soal untuk tipe soal pilihan ganda.

Tabel 4: Indeks Tingkat Daya Pembeda Soal

\begin{tabular}{ll}
\multicolumn{1}{c}{$\begin{array}{c}\text { Indeks Tingkat Daya } \\
\text { Pembeda Soal }\end{array}$} & \multicolumn{1}{c}{ Keterangan } \\
\hline $0,40-1,00$ & Soal diterima dengan baik \\
\hline $0,30-0,39$ & Soal diterima tetapi perlu diperbaiki \\
\hline $0,20-0.29$ & Soal tidak dipakai/dibuang \\
\hline $0,00-0,19$ & Soal diterima dengan baik \\
\hline
\end{tabular}

Sumber: Wahidmurni, 2010, hal. 136

Cara untuk mengetahui daya pembeda soal bentuk pilihan ganda adalah dengan menggunakan rumus berikut ini.

$$
D P=\frac{2(B A-B B)}{N}
$$

Sumber: Wahidmurni, 2010, hal. 135

Keterangan.

DP : Daya pembeda Soal

BA : Jumlah jawaban benar pada kelompok atas

BB : Jumlah jawaban benar pada kelompok bawah

$\mathrm{N} \quad$ : jumlah peserta yang mengerjakan tes

Hasil perhitungan daya pembeda pada soal pilihan ganda (40 soal) dapat dilihat pada tabel berikut ini.

Tabel 5: Hasil Indeks Tingkat Daya Pembeda Soal

\begin{tabular}{cl}
\hline Jumlah Butir Soal & \multicolumn{1}{c}{ Keterangan } \\
\hline 5 & Soal diterima dengan baik \\
\hline 2 & Soal diterima tetapi perlu diperbaiki \\
\hline 24 & Soal tidak dipakai/dibuang \\
\hline 5 & Soal diterima dengan baik \\
\hline
\end{tabular}

Berdasarkan tabel di atas terdapat variasi daya pembeda dalam 40 butir soal pilihan ganda. Jika dipersentase terdapat 22,5\% dapat digunakan, $12,5 \%$ dapat digunakan tapi 
revisi, dan 5\% harus direvisi, dan 60\% harus dibuang. Ada 9 yang dapat digunakan artinya dapat membedakan siswa yang telah menguasai dan belum materi pelajaran yang diujikan. Akan tetapi ada 5 soal yang dapat digunakan tapi harus diperbaiki karena lima butir soal tersebut harus diperbaiki dari sisi alternatif jawabannya atau dengan juga pertanyaannya. Keadaan berbeda pada 2 butir soal yang harus direvisi alternatif jawaban dan juga pertanyaannya karena tidak dapat membedakan antara siswa yang sudah dan belum menguasai materi pelajaran. Selain itu terdapat 24 soal pilihan ganda yang harus dibuang atau diganti karena tersebut tidak dapat membedakan siswa yang telah menguasai dan belum materi pelajaran.

\section{c. Hasil Analisis Daya Pengecoh Butir Soal Pilihan Ganda}

Daya pengecoh khususnya pada soal pilihan ganda adalah kemampuan alternatif jawaban (selain alternatif jawaban yang benar) khususnya pilihan ganda untuk dipilih oleh siswa. Adanya kemampuan ini menjadi salah satu indikator soal pilihan ganda untuk dapat dikatangan berkualitas. Ada beberapa kriteria untuk menentukan berhasil tidaknya pengecoh pada soal pilihan ganda. (1) Minimal dipilih sebanyak 5\% oleh siswa. (2) Lebih banyak dipilih oleh siswa yang belum paham materi pelajaran.

Berdasarkan hasil temuan penelitian ternyata ditemukan dua jenis tipe soal jika dilihat dari daya pengecohnya. Berikut ini pembahasannya.

1) Butir soal pilihan ganda dengan daya pengecohnya baik

Ada 16 dari 40 butir soal yang memiliki butir pilihan jawaban yang mempunyai daya kecoh baik. Dua belas soal tersebut adalah 6 9, 21, 22, 23, 26, 31, 32, 33, 36, 37, 38 dan 39. Dikatakan memiliki daya pengecoh yang baik karena jumlah persentase dari seluruh suluruh siswa kelas VIII dalam memilih alternatif jawaban di tiap soal dari 12 soal tersebut lebih dari 5\%.

2) Butir soal pilihan ganda dengan daya pengecohnya tidak baik

Ada 24 dari 40 butir soal yang memiliki butir pilihan jawaban yang mempunyai daya kecoh tidak baik. Dua puluh empat soal tersebut adalah 1, 2, 3, 4, 5, 7, 8, 10, 11, 12, 13 , $14,15,16,17,18,19,20,24,25,27,28,29,30$ 32, 24, 25 dan 40. Dikatakan memiliki daya pengecoh yang tidak baik karena jumlah persentase dari seluruh suluruh siswa kelas VIII dalam memilih alternatif jawaban di tiap soal dari 12 soal tersebut lebih dari kurang dari $5 \%$.

Menurut Sevi (2015. Hal. 42) menyatakan bahwa adanya kegagalan dari butir soal disebabkan oleh validitas soal. Artinya soal yang disajikan saat ujian tidak bisa atau tidak tepat untuk mengukur atau tidak tepat untuk mengetes siswa sesuai kompetensi yang diujikan. Berdasarkan penelitian yang telah dilakukan. Penyebab tidak validnya soal yaitu daya beda, tingkat kesukaran dan efektifitas pengecoh pada soal pilihan ganda.

Soal yang tidak memiliki daya beda adalah soal yang belum dapat membedakan antara kelokmpok atas dan bawah. Artinya soal tersebut tidak mampu membedakan siswa di kelompok cepat dan kelompok lambat dalam penyerap pembelajaran. Hal ini diperkuat oleh Arikunto (dalam Nurinda, 2014. hal. 79) menyatakan bahwa soal yang baik adalah 
soal mempunya daya pembeda yang baik dan cukup baik. Sementara itu soal yang memiliki daya pembeda jelek sebaiknya direvisi atau dihilangkan.

Soal yang gagal pada aspek tingkat kesukaran dapat diartikan bawah soal yang disusun ada soal yang terlalu mudah dan ada juga soal yang terlalu sulit. Hal ini mengakibatkan soal yang disusun belum mampu mengukur kemampuan peserta tes dengan baik. Menurut Anas (dalam Rahayu, 2016. Hal. 92) menyetakan ada beberapa tindak lanut yang harus dilakukan penyusun terhadap hasil hasil tingkat kesukaran soal. (a) Soal dengan tingkat kesukaran kategori lebih baik disimpan dan bisa dilakukan pada kegiatan tes-tes selanjutnya. (b) Soal dengan kategori sukar dan mudah lebih baik direvisi dan dibuang atau bisa tetap digunakan namun pada kegiatan tes-tes yang sifatnya sangat ketat atau sangat longgar.

Sementara itu, soal yang gagal pada aspek efektifitas daya pengecoh terutama pada pilihan ganda berarti anternatif pada soal pilihan ganda belum berfungsi dengan baik. Hal ini juga dapat diartikan bahwa soal pilihan ganda yang disusun memiliki pilihan jawaban yang mudah ditemukan jawabannya. Hal ini diperkuan pendapat Rokhimah (dalam Nurinda dkk, 2014. Hal. 79) menyatakan bahwa fungsi pengecoh dipengaruhi oleh homogenitas pengecohnya itu sendiri pada soal pilihan ganda. Pengecoh bisa dilihat dari isi atau pesan yang disampikan, kalimat atau pernyataan yang menunjukkan mana pilihan jawaban yang benar. Selain itu, juga ditentukan pada panjang kalimat dari pilihan jawaban.

\section{KESIMPULAN}

Evaluasi pembelajaran memiliki peran yang sangat penting dalam pembelajaran. Hasil akhir dari kegiatan belajar siswa dapat diketahui dengan melaksanakan proses evaluasi. Instrumen evaluasi yang dijadikan objek penelitian adalan nahkah soal ujian semester SMP Muhammdiyah 1 Jember dalam kelas VIII. Soal yang berkualitas membutuhkan serangkaian uji coba atau tes sebelum soal tersebut digunakan untuk menguji siswa pada waktu yang sebenarnya. Butir soal dikatakan berkualitas jika dapat memberikan informasi secara tepat siswa mana yang sudah dan belum menguasai materi yang diajarkan guru. Salah satu cara untuk mencapai butir soal yang berkualitas adalah melakukan analisis butir soal. Kesimpulan hasil dari analisis butir soal ujian semester dalam penelitian ini sebagai berikut.

Pertama, dilihat dari tingkat kesukaran butir soal terdapat 5 jenis tingkat kesukaran di 40 butir pilihan ganda dalam naskah soal ujian semester kelas VIII di mata pelajaran BI. Lima jenis tersebut adalah sangat mudah, mudah, sedang, sukar, sangat sukar untuk tipe soal pilihan ganda. Dengan komposisi, 3 butir soal untuk sangat mudah, 9 butir soal untuk mudah, 22 butir soal untuk sedang, 3 butir soal untuk sukar, dan 3 butir soal untuk sangat sukar. Sementara itu, untuk soal uraian semuanya berkategori sedang. Dengan keadaan seperti ini perlu adanya tindakan revisi pada soal pilihan ganda yang berkategori sangat sukar dan mudah, sukar dan mudah supaya semua soal berkategori sedang.

Kedua, dilihat dari daya pembeda tiap butir terdapat empat jenis tingkat daya pembeda di 40 butir soal pilihan ganda dalam naskah soal ujian semester kelas VIII di mata pelajaran BI. Empat jenis pembeda tersebut adalah, dapat digunakan, digunakan 
dengan revisi, revisi dan dibuang untuk tipe soal pilihan ganda. Dengan komposisi, 9 butir soal dapat digunakan, 5 butir soal dapat digunakan tapi revisi, 2 butir soal direvisi, dan 24 butir soal dibuang. Sementara itu, untuk soal uraian yang terdiri dari 5 soal berkategori dapat digunakan tapi revisi. Dengan keadaan seperti ini perlu adanya perbaikan atau revisi untuk sebagian besar butir soal baik pilihan ganda dan uraian.

Ketiga, dilihat dari daya pengecoh butir soal pilihan ganda yang dipakai saat ujian semester kelas VIII diketahui bahwa terdapat 16 butir soal dengan daya pengecoh baik dan 24 butir soal dengan daya pengeconya tidak baik. Keadaan ini tentunya membutuhkan revisi pada soal pilihan ganda khususnya penyusunan alternatif pilihan ganda.

\section{DAFTAR RUJUKAN}

Basuki, I. \& Hariyanto. (2015). Asesmen Pembelajaran. Bandung: Rosdakarya.

Indriani, F. (2015). Kompetensi Pedagogik Guru dalam Mengelola Pembelajaran IPA di SD dan MI. Fenomena: Jurnal Ilmiah Universitas Ahmad Dahlan Yogyakarta, Indonesia, 17-28.

Karzuni. (2015). Evaluasi Pembelajaran. Bandung Rosdakarya.

Kurniawan, T. (2015). Analisis Butir Soal. Journal of Elementary Education, Universitas Negeri Semarang, 1-6.

Amalia, A. N. (2012). Analisis Butir Soal Tes Kendali Mutu Kelas XII SMA Mata Pelajaran Ekonomi Akuntansi Di Kota Yogyakarta Tahun 2012. Jurnal Pendidikan Akuntansi Indonesia, UNY, 1-26.

Nurinda, S., Ely, R., \& Saiful, R. (2014). Analisis Butir Soal Olimpiade Biologi SMA Tingkat Kabupaten /Kota Tahun 2013. Unnes Journal of Biology Education, 7784 .

Nuriyah, N. (2014). Evaluasi Pembalajaran. Jurnal ilmiah: Edueksos, 73-84

Rahayu, R. (2016). Analisis Kualitas Soal Pra Ujian Nasional Mata Pelajaran Ekonomi Akuntansi. Jurnal Pendidikan Akuntansi Indonesia, 85-94.

Ridwan. (2015). Dasar-Dasar Statistika. Bandung: Alfabeta.

Septiana, N. (2016). Analisis Butir Soal Ulangan Akhir Semester (UAS) Biologi Tahun Pelajaran 2015/2016 Kelas X dan XI Pada MAN Sampit. Jurnal: EduSains IAIN Palangkaraya, 115-121.

Sevi, W. O. (2015). Analisis Butir Soal Ujian Akhir Mata Pelajaran Ekonomi Akuntansi. Jurnal Pendidikan Akutansi, UNY. 35-44

Sugiyono. (2016). Metode Penelitian Kuantitatif, Kualitatif dan R\&D. Bandung: Alfabeta.

Wahidmurni, dkk. (2010). Evaluasi Pembelajaran (Kompetensi dan Praktik). Yogyakarta: Nuha Litera 